\title{
Letter to the editor: Escherichia coli harbouring $m c r-1$ gene isolated from poultry not exposed to polymyxins in Brazil
}

SA Lentz ${ }^{12}$, D de Lima-Morales ${ }^{23}$, VM Cuppertino ${ }^{1}$, LdS Nunes ${ }^{3}$, AS da Motta ${ }^{1}$, AP Zavascki ${ }^{4}$, AL Barth $^{3}$, AF Martins $^{13}$

1. 1. ICBS - Instituto de Ciências Básicas da Saúde, UFRGS - Univ. Federal do Rio Grande do Sul, Porto Alegre, RS, Brazil

2. These authors contributed equally to this work.

3. LABRESIS - Lab. de Pesquisa em Resistência Bacteriana, HCPA - Hosp. de Clínicas de Porto Alegre, Porto Alegre, RS, Brazil

4. Infectious Diseases Service, Hospital de Clínicas de Porto Alegre, Porto Alegre, RS, Brazil

Correspondence: Afonso Luis Barth (albarth@hcpa.edu.br)

Lentz SA, de Lima-Morales D, Cuppertino VM, Nunes LdS, da Motta AS, Zavascki AP, Barth AL, Martins AF. Letter to the editor: Escherichia coli harbouring mcr-1 gene isolated from poultry not exposed to polymyxins in Brazil. Euro Surveill. 2016;21(26):pii=30267. DOI: http://dx.doi.org/10.2807/1560-7917.

ES.2016.21.26.30267

To the editor: The recent paper by Fernandes et al. [1] described the presence of the mcr-1 gene in Escherichia coli from pigs and poultry in Brazil. The authors stated that microbiology laboratories worldwide should be aware of $m c r-1$ isolates resistant to polymyxins in patients living in or returning from Latin American countries and highlighted that the $m c r-1$ gene dissemination results from polymyxins' misuse as growth promoter in food animals. In view of the concerning spread of antibiotic resistance, we screened $E$. coli isolates obtained from a poultry slaughterhouse in southern Brazil with official reports on antibiotic use.

Poultry rectal swabs were collected between August and October 2015. A total of 340 chickens farmed in Brazil and belonging to 17 batches were included in the study. All poultry had received bacitracin, narasin and nicarbazin during a first period of life (between the 2nd and the 18th day) and avilamycin and salinomycin during a second period (between the 2oth and 35th day); the chickens of batches 10 and 11 had also received doxycycline during at total of 3 days, in the second period of life. Poultry included in this study were not exposed to polymyxin during their entire life (around 40 days).

A total of 343 isolates were evaluated by polymerase chain reaction (PCR) for the $m c r-1$ gene [2] and 10 (3\%) were positive. The $m c r-1$ gene was confirmed by sequencing the PCR amplicon. The $m c r-1$ positive isolates were obtained from 10 different chickens belonging to three batches from three different breeders. The polymyxin B minimum inhibitory concentrations (MIC) of the $10 \mathrm{mcr}-1$ positive isolates were $2 \mathrm{mg} / \mathrm{L}$ (8 isolates), $1 \mathrm{mg} / \mathrm{L}$ and $0.25 \mathrm{mg} / \mathrm{L}$ and they could be classified as susceptible to polymyxin B, according to the European Committee on Antimicrobial Susceptibility
Testing (EUCAST) (resistance $>2 \mathrm{mg} / \mathrm{L}$ ). In contrast, most reports indicate that the $m c r-1$ gene is usually found in isolates presenting resistance to polymyxins [2-6].

The mcr-1 positive isolates were submitted to DNA macrorestriction typing by pulsed-field gel electrophoresis (PFGE) and five isolates, from the same batch, proved to be clonally related while the other five isolates were unrelated. Conjugation experiments with the $E$. coli J 53 were successful for two $m c r-1$ positive isolates which confirmed that the mcr-1 gene was located in a plasmid. The transconjugants presented positive results by PCR for the $m c r-1$ gene and had a polymyxin B MIC of $2 \mathrm{mg} / \mathrm{L}$.

According to Brazilian law, all slaughterhouses must submit in advance to the Federal Inspection Service of the Ministry of Agriculture, the bulletin of health of each batch of animals to be slaughtered. It is of note that the chickens evaluated in this study have received antibiotics as growth promoters, but polymyxins were not included among these compounds. This goes against the hypothesis that the emergence of the mcr-1 gene is linked to the use of polymyxins in animal feed in Brazilian livestock [1] and suggests that others compounds or factors may also be involved in the selection of this gene.

Finally, the fact that the $m c r-1$ was originally described in China and thereafter in several other countries including Europe indicates that this gene is already widespread in the world. Therefore, isolates with $m c r-1$ should be considered in any patient, regardless of whether they were living in or returning from Latin America or not. 
On 3 August, the Acknowledgements section was modified to include Laurent Poirel and acknowledge his provision of an mcr-1 positive control.

\section{Acknowledgements}

The authors would like to thank Amanda Silva Martins and Zelia Fonseca Vieira for the technical support and Laurent Poirel for providing an mcr-1 positive control*. This study was funded by $\mathrm{CNPq}$ - Conselho Nacional de Desenvolvimento Científico e Tecnológico and FIPE - Hospital de Clínicas de Porto Alegre.

\section{Conflict of interest}

None declared.

\section{Authors' contributions}

Conceived the project: AFM; Managed sample collection: SAML, ASM, AFM; Performed laboratory investigations: SAML, DLM, LSN, VMLC; Drafted the article: DLM; Revised the article: APZ, ALB, AFM.

\section{References}

1. Fernandes MR, Moura Q, Sartori L, Silva KC, Cunha MP, Esposito F, et al. Silent dissemination of colistin-resistant Escherichia coli in South America could contribute to the global spread of the mcr-1 gene. Euro Surveill. 2016;21(17):30214. DOI: $10.2807 / 1560-7917 . E S .2016 .21 .17 .30214$ PMID: 27168587

2. Liu Y-Y, Wang Y, Walsh TR, Yi L-X, Zhang R, Spencer J, et al. Emergence of plasmid-mediated colistin resistance mechanism MCR-1 in animals and human beings in China: a microbiological and molecular biological study. Lancet Infect Dis. 2016;16(2):161-8. DOI: 10.1016/S1473-3099(15)00424-7 PMID: 26603172

3. Elnahriry SS, Khalifa HO, Soliman AM, Ahmed AM, Hussein AM, Shimamoto T, et al. Emergence of Plasmid-Mediated Colistin Resistance Gene mcr-1 in a Clinical Escherichia coli Isolate from Egypt. Antimicrob Agents Chemother. 2016;60(5):324950. DOI: 10.1128/AAC.00269-16 PMID: 26953204

4. Malhotra-Kumar S, Xavier BB, Das AJ, Lammens C, Hoang HTT, Pham NT, et al. Colistin-resistant Escherichia coli harbouring mcr-1 isolated from food animals in Hanoi, Vietnam. Lancet Infect Dis. 2016;16(3):286-7. DOI: 10.1016/S14733099(16)00014-1 PMID: 26774248

5. Rapoport M, Faccone D, Pasteran F, Ceriana P, Albornoz E, Petroni $A$, et al. First description of mcr-1-mediated colistin resistance in human infections caused by Escherichia coli in Latin America. Antimicrob Agents Chemother. 2016;60(7):44123. DOI: 10.1128/AAC.00573-16 PMID: 27090181

6. Ye H, Li Y, Li Z, Gao R, Zhang H, Wen R, et al. Diversified mcr1-Harbouring Plasmid Reservoirs Confer Resistance to Colistin in Human Gut Microbiota. MBio. 2016;7(2):e00177-16. DOI: 10.1128/mBio.00177-16 PMID: 27048797

\section{License and copyright}

This is an open-access article distributed under the terms of the Creative Commons Attribution (CC BY 4.0) Licence. You may share and adapt the material, but must give appropriate credit to the source, provide a link to the licence, and indicate if changes were made.

This article is copyright of the authors, 2016. 